\title{
Contemporaneous Loan Stress and Termination Risk in the CMBS pool: how "Ruthless" is Default?
}

\author{
By \\ Tracey Seslen \\ Marshall School of Business \\ University of Southern California \\ William C. Wheaton \\ Department of Economics \\ MIT
}

Current version: September 2005

\begin{abstract}
This study analyzes the impact of contemporaneous loan stress on the termination of loans in the commercial mortgage-backed securities pool using a novel measure, based on changes in net operating incomes and property values at the MSA-property type-year level. Employing a semi-parametric competing risks model for a variety of specifications, we find that the probability of default is extremely low even at very high levels of stress, even though the point estimates of greatest interest are very statistically significant. These results suggest substantial lender forbearance and a possible reluctance to foreclose, and are consistent with previous literature measuring/modeling the incidence of default where such option is "in the money".
\end{abstract}




\section{Introduction}

The last 15 years have seen significant fluctuations in commercial property markets across the country: recession and collapse during the late 1980s and early 1990s, recovery in the late 1990s, and downturn yet again with the events of September $11^{\text {th }}$. During much of this period, default rates on commercial loans have moved strongly with these market trends: soaring in the late 1980s - early 1990s and then falling steadily with market recovery in the 1990s. Recently, however, they have remained low despite the market stress after September $11^{\text {th }}$. So how does one go about explaining this phenomenon?

The recent empirical literature on commercial loan termination - default and prepayment - largely has focused on the underwriting stringency applied to the loan at the time of origination and then the subsequent pattern of interest rates, credit spreads, and other characteristics of the broader financial markets. With regard to the ongoing state of the collateral behind the loan, researchers have not used contemporaneous measures of loan stress or else tried rudimentary proxies such as geographical and property-type fixed effects. This omission has undoubtedly led to biased results and leaves unanswered many questions that have been raised in the contingent claims theoretical literature regarding the conditions under which termination options are actually exercised. Without this understanding it is difficult to explain the low default outcomes in recent years as opposed to those much higher rates during the last period of market stress.

In this paper, we hope to remedy the shortcomings of the previous literature and answer some key questions that have so far been inadequately addressed. First, are the low levels of recent default due to the fact that the market simply has not been that bad, or because of reluctance on the part of borrowers to default when faced with an underwater loan or an inability to make payments? Along similar lines, is default immediate (i.e. "ruthless") or gradual when a state of stress is reached? And what does this imply about lender "forbearance” and a possible reluctance to foreclose?

To answer these questions, we turn to a commonly used database of commercial loans, and augment it with a novel set of indices representing market conditions at the MSA-property-type-year level. Central to our analysis is the creation of a contemporaneous measure of estimated loan-to-value (LTV) and debt service coverage 
ratio (DSCR) that captures the yearly impact of local market and property sector forces on loan collateral. To the extent that market forces drive actual property LTV and DSCR, these measures should strongly impact the termination decision. According to the contingent claims theory of mortgage pricing, the higher the LTV or the lower the DSCR then the higher should be the probability of default, and in the absence of a prepayment lockout, the lower the probability of prepayment. Inclusion of only initial levels of loan stress should lead to significant omitted variable bias, affecting both the coefficient estimates and the estimated baseline hazard of default.

Another key component of our analysis is the notion that parametric estimation techniques, based in this case on an underlying logistic distribution, may be insufficient for properly modeling the conditional probability of default. We hypothesize that the probability of default rises more rapidly with a DSCR $<1.0$ than it falls with a DSCR $>1.0$ (similarly LTV $><1.0$ ). We employ a spline specification within the logistic model to test this hypothesis.

We ultimately find that contemporaneous measures of LTV and DSCR have highly significant impacts on the probability of prepayment and default, however, our point estimates of the conditional probability of default however show remarkably small increases in delinquency as DSCR falls below or LTV rises above one. In addition, the impact of LTV gets washed out when both measures are included simultaneously. Incorporating the spline specification, we find that the probability of default is, indeed, more steeply sloped at levels of DSCR less than one, although the probability is still far less than what so called "ruthless" default models predict.

In the end our results point towards two conclusions. First, there could be a reluctance to default given a state of high current loan stress - at least over the study period (1992-2003). This suggests greater forbearance by lenders towards delinquent borrowers or prohibitive penalties for default by borrowers. The probabilities of default estimated from the spline specification also suggest that at low levels of stress, default may be significantly more idiosyncratic in nature, while at higher levels of stress, default may be a result of more systematic, market-related forces. This raises a second conclusion: that our results may be driven by the fact that actual property measures of loan stress are only weakly correlated with market movements and it is this fact that 
accounts for our "gradual” relationship between the two. Overall, though, the inclusion of a contemporaneous measure of loan stress based on market changes at the MSAproperty-type-year level represents a significant improvement over the previous literature and sets a new benchmark for future work.

The remainder of the paper is organized as follows. We begin with a brief summary of the previous literature relevant to our study, followed by an introduction to the commercial mortgage-backed securities (CMBS) market. Due to the concentrated and fairly centralized nature of the CMBS market, and the demands by securities analysts for clean and accurate data, the CMBS market has become an important new source for data on commercial loans. Virtually every piece of empirical literature on commercial loans, prior to the last few years has employed data from the same small handful of insurance companies. Such unsecuritized loans might differ in ways that could influence our conclusions, and in this section, we attempt to identify those issues. Next, we introduce the actual data employed in our analysis. We then describe our empirical strategies and present our results. A final section offers up discussion and conclusions.

\section{Commercial Mortgage Research}

The literature on commercial mortgages falls into two camps: theoretical and empirical. Contingent claims theory models have long recognized since the early 1990s that prepayment and default are competing risks, with prepayment largely driven by interest rate movements and volatility while default is driven by the movements and volatility of collateral value. Using simulation with estimated parameter values for the interest rate and value movements, Kau, Keenan, Muller and Epperson (1990) is one of the earlier examples of such an approach. In most early theoretical papers, the default or prepayment option is exercised as soon as it is "in the money", which is termed "ruthless" default.

Only a few years later, several theoretical papers began to question the notion of “ruthless” default. Kau, Keenan and Kim (1994), Riddiough and Thompson (1993) and Riddiough and Watt(1994) all presented models in which there was “gradual” termination as the option to terminate a loan approached the hurdle value. Each model relied on a different explanation, such as cross-collateralization, strategic behavior, or 
noisy information signals, but the implication was the same: that "gradual" default would significantly change mortgage valuations.

Empirical work on commercial mortgages began with Snyderman's descriptive analysis of Life Company loan defaults. Snyderman and subsequently Esaki (1999) found a baseline probability of default that is hump-shaped with respect to loan age. However, lacking other covariates and any econometric analysis it is difficult to know whether this represented some true "seasoning” effect or the state of loan stress associated with loans of different ages. Once econometric models were applied to similar private mortgage data pools, researchers found strong evidence of “gradual” defaults. Vandell (1992) and Vandell et al. (1993) demonstrated that default probabilities seem to rise gradually with increases in a very crude estimate of contemporaneous LTV. Lekkas, Quigley and Van Order (1993) showed that loan loss experience is substantially less than would be predicted by "ruthless" default, and Follain and Ondrich (1997) showed that prepayment is also not automatic once "in the money". Other similar studies examining either prepayment or default using agency-based data on multifamily properties include McConnell and Singh (1994), and Ciochetti and Vandell (1999). In all of this empirical research, defaults or prepayments were modeled as single events and not competing risks. Deng, Quigley, and Van Order (2000) made a significant advancement in the literature by presenting a unified empirical model in which prepayment and default are competing risks. Their residential study shows that the simultaneity of the two outcomes is important in explaining termination behavior. Initial LTV is found to play a significant role in both prepayment and default when incorporated nonlinearly. Ambrose and Sanders (2003) are the first to utilize this competing risk (prepayment-default) empirical model to study a broad group of commercial mortgages. They are also the first to apply such analysis to CMBS loans. With a multinomial logit model their study finds no effect of initial LTV (incorporated linearly), but the authors argue that this could be due to endogeneity - loans that are more intrinsically more risky are underwritten more stringently.

In the current study, we combine all of the best features of this previous work as well as several improvements. Our contributions are as follows: 
1. We use a full competing risk model of both prepayment and default that incorporates full fixed effects for loan age to uncover any true seasoning effect.

2. We advance the Vandell et al. (1993) use of contemporaneous LTV by developing yearly contemporaneous estimates of both LTV and DSCR that are both property-type and MSA specific - rather than using a single regional index.

3. We explore for the first time the exact detailed relationship between contemporaneous loan stress and default with several parametric and "flexibly"parametric specifications - finding overwhelming evidence of very gradual default.

\section{The Commercial Property Market and Mortgage Defaults}

Generally speaking, the commercial real estate market has been through two "cycles" during the last 25 years. Figure 1 illustrates this in the case of office properties. After a tight market in the late 1970s, rents (in constant \$) were high and vacancy low throughout the early 1980s. Then as vacancy rose and leveled off, rents dropped continuously, reaching a bottom in 1992. From then on there was a market recovery, until September $11^{\text {th }}$ created another spike in vacancy and downturn in rents. The market is expected to gradually recover going forward.

Figure 2 shows that during this time frame, real estate pricing has been generally backward rather than forward looking. Low cap rates throughout the 1980s reflected unmitigated optimism rather than anticipating the downturn around 1990, and high cap rates in the early 1990's failed to reflect the subsequent recovery. It is sometimes argued that the low cap rates (high prices) in recent years may be due to record low interest rates rather than reflecting a change in investor expectations - in this case anticipating the forecast recovery.

Defaults among commercial loans as a whole have tended to follow these market movements. Figure 3 compares the default experience of the Life Insurers (the largest private pool of commercial mortgages) with the valuation of properties in the NCREIF pool. Rising asset prices in the early 1980s kept defaults low, just as stagnant or falling 
asset prices from 1987-1995 generated defaults not seen since the Great Depression (Esaki, et al.). From 1996 on, a recovering market and falling cap rates (Figure 2) have generated asset appreciation - and very low defaults.

Figure 1: US Office Rents versus vacancy, with forecast, 1980-2010

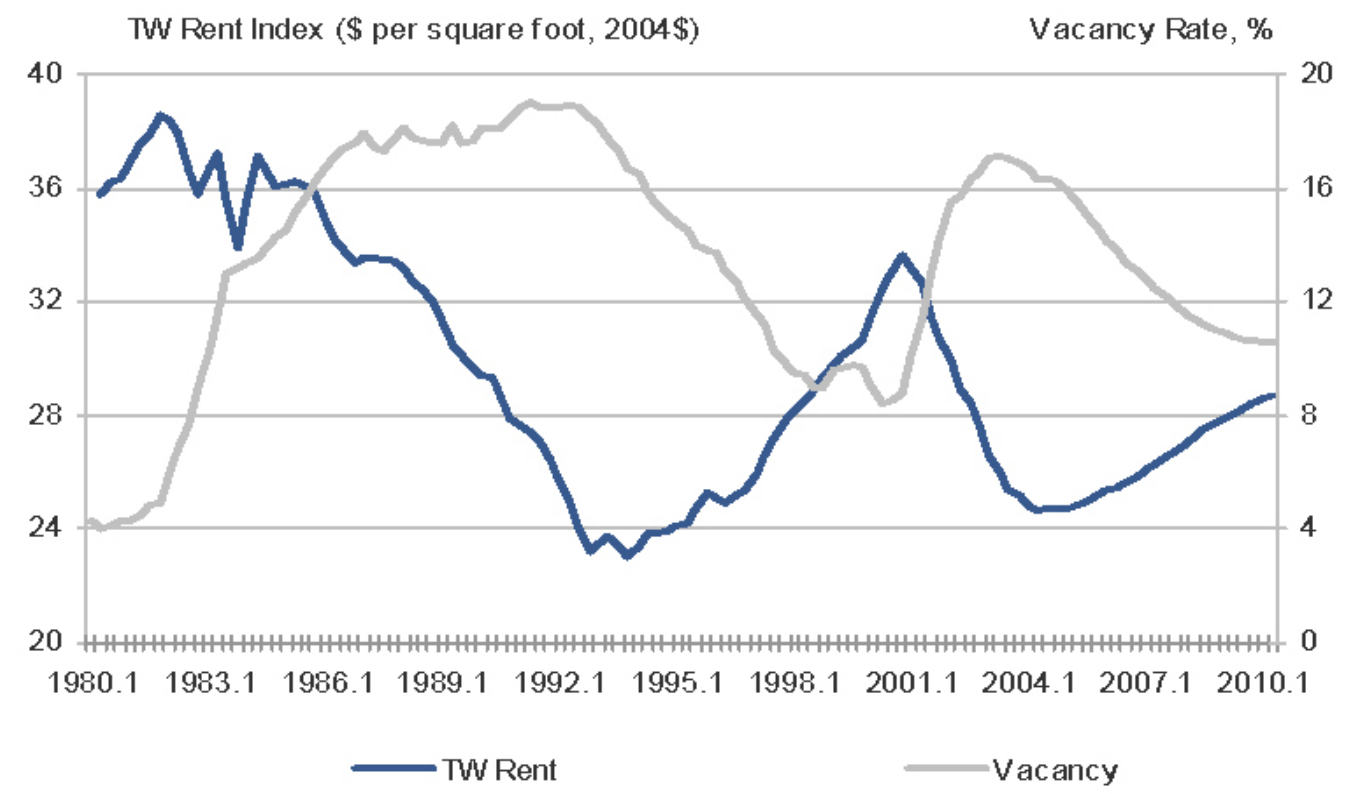

Figure 2: Cap Rates for Four Major Property Types, 1980-2004

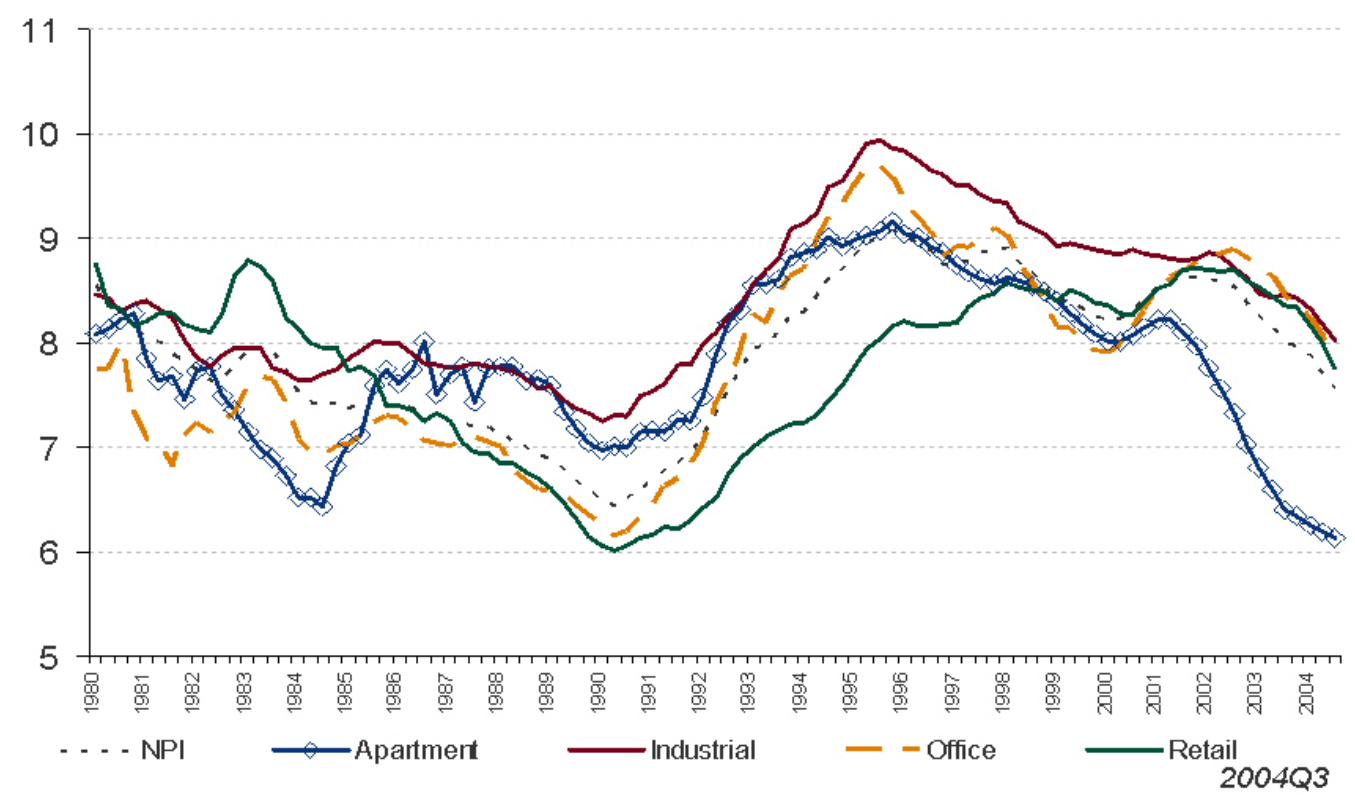


Figure 3: Commercial Loan Defaults (Esaki) and Commercial Real Estate Trends (NCREIF), 1978-2001

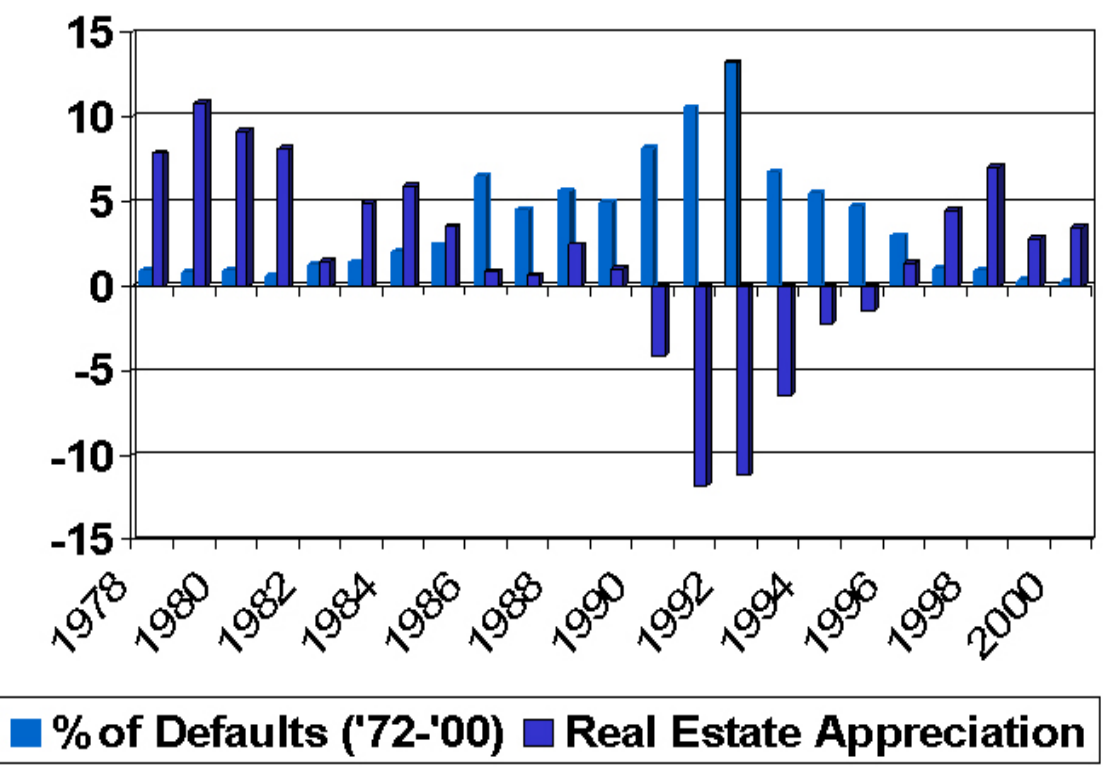

Despite the market downturn after September $11^{\text {th }}$, there has been little increase in defaults. With the relatively short recovery in rents, net operating incomes did not have a chance to rise much between 1996 and 2001 and as a result property income fell only moderately thereafter. Furthermore, lower interest rates and falling cap rates (Figure 2) have kept asset prices strong, unlike the period 1987-1995.

\section{The CMBS Market}

The CMBS market is one of the younger and less-developed securities markets in the U.S., but has become a rapidly growing source of capital to commercial lenders. The CMBS market currently has around 200 pools comprised mostly of loans that were originated since the start of commercial mortgage securitization in the early 1990s. The default rate of these loans has been quite low - generally less than $2 \%$ lifetime. Loans originated in 1992-1995 were very conservatively underwritten and behaved very differently in those years than did older loans, originated at the market peak a decade prior.

Before being placed in the pool, the loans are carefully examined under a number of risk-based criteria and the pool itself is rated by one of the major agencies. The pool's 
income, which constitutes the payout to investors, is divided into risk "pieces," (i.e. "A", "B", etc.) which represent positions on the payout ladder. The lower down the ladder the piece is, the riskier the investment. Presently, there is an active market for trading in shares of pieces among investors, and yields vary widely between the most secure and riskiest pieces. In terms of operating mechanics, a "regular" loan servicer is responsible for breaking down pool funds and sending them to investors.

With regard to the composition of the pool itself, loans may be of virtually any size and from any property type. Contrary to popular belief, the loans that eventually wind up in the pool are at no greater risk of default, on average, than un-securitized loans. In fact, the rating agencies for CMBS pools tend to engage in a more rigorous process of due diligence than the originators themselves. This may have helped avoid the potentially troublesome adverse-selection problem that is inherent in the system if the originators have superior "inside" information about loan risk.

When a loan does turn sour - a delinquency of 60+ days or outright default - then a "special" servicer takes over all payment collections from the regular servicer. The special servicer is paid with fees, rather than a share of residual value. This would seemingly create an incentive towards more ruthless pursuit of foreclosure than in the whole loan market. As of yet, however, we have no evidence to support or refute this claim; with the market being so young, there has not been a "hundred year flood" to test this hypothesis.

\section{Data and Empirical Methods}

To carry out our analysis, we employ data from two major sources. Loan characteristics and delinquency histories come from the Trepp CMBS data collection service. The raw dataset of loan characteristics is a flat file representing 78,344 securitized commercial loans. Each record contains information on the origination date, the maturity date, the interest rate (and indexing, if variable), the loan amount, the property location and type, the prepayment lockout and yield maintenance provisions (if any), the prepayment date (if applicable), the LTV at origination and the DSCR as of a particular report date. The delinquency history contains one record for every "credit event” experienced by any loan in the sample, with the type of event (30 day 
delinquency, 60 days, 90+ days, foreclosure, bankruptcy, performing/non-performing balloon, or real estate owned) and the date of occurrence. Every month of delinquency is reported.

Our second source of data is a set of indices from Torto Wheaton Research that are specific to each market (MSA), property type (office, retail, etc.) and year. These track changes in property values and net operating incomes for "average" properties and comprise much greater detail than the single index used by Vandell et al. (1993). We use these indices to generate our variables of greatest interest to our study - contemporaneous LTV and DSCR. We use this set of indices to update the static values of LTV and DSCR contained in the Trepp database in the following way:

$$
\begin{aligned}
& L T V_{t}=L T V_{0} *\left(\text { Value }_{0} / \text { Value }_{t}\right) \\
& \operatorname{DSCR}_{t}=\operatorname{DSCR}_{0} *\left(\mathrm{NOI}_{t} / \mathrm{NOI}_{0}\right)
\end{aligned}
$$

To account for variation in the month of origination, and the fact that there exists only one index per calendar year, the indices ultimately applied to the reported LTV and DSCR values are a weighted average of the current and following year's indices.

The raw Trepp data were filtered to exclude any loans with origination dates prior to securitization in 1992 , loans with balances at origination of less than $\$ 1,000,000$, and those with missing or non-sensible entries for the set of essential of loan characteristics. The initial LTV was bounded between 0.1 and 1.5, while "as of” DSCR was bounded between 0.5 and 5 . The application of these filters reduced the sample size by approximately half. The final sample was obtained by applying two additional filters: the requirement that the loan be at least six months old, and that the MSA-property typeyear combination match the ones for which TWR property value or NOI indices existed. In the end, the sample size varied with the choice of specification, our definition of delinquency and the choice of measure representing loan stress. Given the strong increase in both property values and NOI over the sample period of 1992-2002, the number of actual defaults was very low, so we chose to analyze delinquency at 60 and $90+$ days to insure enough variation to generate precise estimates. Figures $4 \mathrm{a}$ and $4 \mathrm{~b}$ 
show the trends in these two variables over our sample period for the four major types of property in the Boston market.

The final sample contained approximately 20,000 loans, representing multihousing (37\%), retail (29\%), office (22\%) and industrial (12\%) properties. The average LTV at origination was 0.67 (a decline of only 0.02 from the initial sample of 78,000) and the average estimated DSCR at origination was $1.49^{1}$. The average loan was valued at \$7.2 million with a standard deviation of about \$16 million. The average spell length was 4.25 years, taking into account both performing (right-censored) and terminated loans. Loans remained in the sample for their first performing spell only. If a loan experienced a delinquency indicating "failure" according to our specification, the loan was not put back into the sample even if it returned to performing status. Depending on the specification, between 2 and 2.5\% of loans fell delinquent and around 8\% prepaid.

To analyze the impact of contemporaneous loan stress on the loan termination decision, we employ a "semi-parametric" competing risks estimator, modeled as a panel multinomial logit with loan age fixed effects. We employ this model based on the belief that default/delinquency and prepayment are substitutes for one another, resulting in correlated error terms across outcomes. If we do not take into account this correlation, our analysis will produce biased estimates. We favor the semi-parametric method in particular, given prior evidence that the (conditional) baseline hazard is hump-shaped, as evidenced in Snyderman (1991) and Deng, Quigley, and Van Order (2000). The set of loan age fixed effects serves as a fully flexible representation of the baseline hazard function, measuring the probability of default or prepayment at time $t$ conditional on performance through period $t-1$, all else equal. The underlying error distribution of the logit specification allows us to accommodate the fact that the credit event histories are not independently and identically distributed.

Formally, in any given period, $t$, each loan, $i$, may experience one of three outcomes, $j$ : it may continue to perform $(j=0)$, it may fall into delinquency $(j=1)$, or it may prepay $(j=2)$. Let $\mathrm{N}$ be the set of loans in the sample, and $\mathrm{T}$ be the set of periods over which a loan is observed. Additionally, let

\footnotetext{
${ }^{1}$ Since DSCR is only reported once, "as of" a particular date, the DSCR at origination is obtained through our standard adjustment procedure: $D S C R_{0}=D S C R_{t} *\left(N O I_{0} / N_{t}\right)$
} 
$y_{i j t}=1$ if loan $i$ in period $t$ experiences outcome $j$ and 0 otherwise

and

$p_{i j t}=P\left(y_{i j t}=1\right)$

$j=0,1, \ldots J, i \in N, t \in T_{i}$.

Under the logit specification, we model the outcome probabilities, conditional on $x_{i t}$ and $\alpha_{i}$ as:

$p_{i j t}=\frac{\exp \left(v_{i j t}\right)}{\sum_{k=0}^{J} \exp \left(v_{i k t}\right)}, \quad v_{i j t}=\left\{\begin{array}{ll}x_{i t} \beta_{j}+\alpha_{i}, & j=1, \ldots, J \\ 0, & j=0\end{array}\right.$,

where $x_{i t}$ is a row vector of our covariates and $\beta_{j}$ is the column vector of coefficients specific to outcome $j . \quad \alpha_{i}$ is a common, random, loan-specific effect that is normally distributed with mean zero and standard deviation $\sigma_{\alpha}$. By our formulation, we assume that the coefficients are the same for all loans in all periods, that the explanatory variables are the same across outcomes, and that the random heterogeneity, $\alpha_{i}$, is specific to loan $i$, but independent of the outcome that occurs. ${ }^{2}$

To carry out our analysis, we estimate a variety of specifications, employing initial and contemporaneous loan stress, linear and bracketed measures of each, changes in loan stress, and interactions between initial measures and changes. In our final specification, we carry out a specification check of the "parametric" aspect of our competing risks model through the use of splines on contemporaneous DSCR. Results can be found starting in Table 1a. Common to all specifications are an additional set of explanatory variables representing various loan characteristics and macroeconomic conditions. These variables mirror those in Ambrose and Sanders (2003), where we were able to recreate them. Their definitions can be found in Appendix 1.

\footnotetext{
${ }^{2}$ See McFadden (1984) for further details on this specification.
} 


\section{Results}

We began our analysis with a basic model, including only initial values of loan stress, as a means of comparison with the previous literature. We can interpret the coefficients of our model as hazard ratios, based on the underlying proportional hazard framework of the multnomial logit model. The likelihood of a termination outcome increases or decreases with a change in the variable of interest according to the formula $e^{\beta}-1$. Employing only initial LTV as our measure of loan stress, we do observe a statistically significant increase in the probability of delinquency with an increase in initial LTV, and a statistically significant decrease in the probability of prepayment (Table 1a). This is contrary to Ambrose and Sanders (2003), which found no impact of LTV on either termination outcome. Breaking down initial LTV into a set of indicator variables, representing brackets of 0.6 to $0.8,0.8$ to 0.9 , and 0.9 to 1.5 , we do not observe the expected monotonic increases in the probability of delinquency. Both the 0.6 to 0.8 bracket and 0.8 to 0.9 show an increase in the probability of delinquency over the omitted category (LTV<0.6), but the indicator for the "most-stressed" category (0.9 to 1.5) is both insignificant and near zero. Under the prepayment outcome, the coefficients have the expected signs and are monotonically decreasing in magnitude with initial LTV; however, none are significant. We saw no improvements in the results breaking down the range of LTV values in several other ways. Overall, the explanatory power of initial LTV is questionable. Though it may be an adequate measure of the underlying creditworthiness of the borrower, it is likely an insufficient proxy for loan stress. Inclusion of initial LTV only, instead of a true contemporaneous measure is likely to cause omitted variable and/or mis-measurement bias that will have an impact both on the regression coefficients and the baseline hazard estimates.

With regard to DSCR, this variable is not utilized in recent literature, given that the CMBS data providers do not report DSCR at origination, but only "as of" a particular date, which may vary widely across loans. Without any means of "updating” DSCR to a particular uniform period, the provided measure is effectively worthless. Because we now have a means of updating - via the MSA-property level-year NOI index - we may now make use of this variable. We must be careful to note, however, that the accuracy of our included variable will vary depending on when the observed DSCR measure was 
reported. The error will likely be greater, the further away our observation period from the report date.

With “initial” DSCR replacing initial LTV as our proxy for loan stress / creditworthiness, we observe stronger results (Table 1b). An increase in initial DSCR leads to a statistically significant decrease in the probability of delinquency, and a small but statistically significant increase in the probability of prepayment. Breaking the linear measure into a set of indicator variables, we observe a monotonic change in the coefficients as the bracket increases. An initial DSCR of 0.5 to 0.8 leads to a neardoubling of the probability of default, and a $23 \%$ decrease in the probability of prepayment, other things held equal. The results show a slightly nonlinear pattern in the likelihood of default as the DSCR falls. Overall, initial DSCR performs much better than initial LTV in the basic model. These results may be due, in part, to DSCR being a more direct measure of the economic health of the property and the ability of the borrower to service the debt. ${ }^{3}$

With regard to the other covariates in the basic model, presence of a prepayment lockout clause has a significant negative impact on the probability of prepayment, but no effect on delinquency. Having the lockout period end in the current year has a substantial positive impact on the probability of both termination outcomes. The presence of a yield maintenance clause does not have a strong influence on either outcome, across most specifications. By way of the variable PPOPTION, we see that loans are more likely to prepay when prepayment is "in the money", but they're more likely to default as well. Quite possibly falling rates are picking up some proxy for market or loan stress as well. The steeper the yield curve, the less likely the loan is to prepay, while the higher the credit spread, the more likely the loan is to prepay. Neither of these two covariates has a large or statistically significant impact on the probability of default. The volatility in the 10-year Treasury rate and the credit spread volatility both have very strong, negative impacts on both termination outcomes. If we look to option pricing theory for an explanation, this result appears to be counterintuitive: as the volatility in interest rates or

\footnotetext{
${ }^{3}$ In this and all further specifications, estimation was carried out with both 60-day and 90+-day delinquency as one of the two termination options. Due to extreme similarities in the estimates using each of the two measures, only the 60-day results will be reported and discussed in the text. The 90+-day results are available from the authors upon request.
} 
credit spreads increases, the value of termination option should increase as well.

Ambrose and Sanders (2003) argue, however, that it is the future value of the termination option that has increased. Therefore, the probability of termination in the current period should decline. Finally, location of the property in a smaller MSA lowers the likelihood of prepayment, but has little impact on the probability of default. The expected sign of this coefficient for each outcome is somewhat unclear. While properties in smaller MSAs are more exposed to market risk - and thus more likely to terminate, all things equal -property markets in smaller MSAs may be more "monopolistic" in nature, which would make them potentially less responsive to any given shock.

In the next stage of the analysis, we move beyond the techniques employed in the previous literature and replace the initial LTV and DSCR measures with our constructed measure of contemporaneous loan stress (Table 2). As expected, an increase in contemporaneous DSCR leads to an increase in the probability of default, while an increase in contemporaneous LTV leads to a decrease in the probability of default. Both coefficients are highly significant. For the prepayment outcome, both coefficients have the expected magnitude, but only DSCR is statistically significant. If we include both measures of loan stress simultaneously, in a "double trigger" model of sorts, the effect of DSCR washes out the effect of the LTV ratio. Given the strong correlation between the two measures, such a result is not surprising.

In Figures 5a through 6d we use the estimates from our specifications thus far to calculate the probability of loan termination over the range of values for initial loan stress and the contemporaneous value. The sample means were employed for all of the other covariates. Even with low default rates observed in the sample, the estimated probabilities under extreme levels of stress are puzzlingly low - we observe less than 2.5\% at the lowest levels of initial and contemporaneous DSCR. For LTV, the probability of delinquency is, likewise, around $2.5 \%$ at the highest levels of contemporaneous stress and $1.5 \%$ at the highest levels of initial LTV.

These results are of significant concern to us, given that no loan should be performing with NOIs of less than half of debt service, or loan amounts that are $50 \%$ greater than the estimated property value. In the second stage of our analysis, we turn to several additional specifications to attempt to uncover some answers. We hypothesize 
that a specification error may be influencing our results, and that the true impact of loan stress on default is not adequately captured through a pure linear measure of our variables of interest. We test this hypothesis next by incorporating bracketed values of loan stress, interactions, and spline terms.

In Tables 3a and 3b, our notion of DSCR as the more appropriate measure of loan stress is further reinforced. Breaking the contemporaneous measure of DSCR into bracketed values, we observe a monotonically increasing, nonlinear pattern in the probability of default as loan stress increases. We do not observe a similar pattern for LTV, nor do we observe the "expected” impact of either measure on the probability of prepayment.

In Tables 4a and 4b (column 1), we decompose the contemporaneous measure of loan stress into the initial component and change since origination, to gain further insight into the impact of changes in local property market conditions - does the manner in which you arrive at a particular level of stress matter, or only the level of stress at which you end up? In mathematical terms, is the risk at time $t$ different for a loan with initial DSCR $=X$ and a change in DSCR since origination of $+Y \%$, versus a loan with initial DSCR $=(1+Y) * X$ and no market-based change in DSCR? Employing DSCR as the measure of loan stress, we observe that the effect of market changes is greater than that of initial underwriting. In other words, the conditional likelihood of delinquency is higher when reached due to a change in NOI relative to an initial position of low debt service coverage. For LTV, the effects of the market and initial underwriting components are nearly equal.

In columns 2 and 3, we build upon the specification incorporating both initial values and changes in loan stress to include bracketed measures of initial loan stress and interactions between the bracketed measures and the changes. Where DSCR is our measure of interest, we observe monotonic increases in delinquency with each decreasing bracket of initial DSCR. When the bracketed values are interacted with the change in DSCR, we observe a monotonic decrease in delinquency as the positive change is applied to lower initial levels of DSCR. For the prepayment outcome, we do not observe as strong of patterns of monotonicity or statistical significance in general. Interacting the change in DSCR with the initial DSCR as a continuous measure (column 5), we do not 
estimate a statistically significant coefficient for the delinquency outcome. Using LTV as our measure of interest, we observe much, much weaker results: fewer "expected” patterns, and much weaker significance across all specifications.

As a final specification, we incorporate a spline knot, on the assumption that a single, continuously differentiable probability distribution underlying the multinomial logit model is insufficient for capturing the effects of loan stress on the termination outcomes. The spline knot allows us to fit a different probability distribution to values of LTV or DSCR above and below a particular threshold. To be consistent with option value theory, we use the threshold of 1.0. At levels of LTV above 1.0 and DSCR below 1.0, default is "in the money," so we would expect to see a sharper rise in the probability of delinquency than at values for which default is not in the money. At values of DSCR below 1.0 or values of LTV below 1.0, the impact of contemporaneous DSCR or LTV is “augmented” by the coefficient on the knot. Formally,

$\operatorname{Pr}\left(\right.$ default $\left._{i t}\right)=\left\{\begin{array}{lc}\alpha_{i}+\beta_{D S C R} D S C R+\beta_{K N O T}(D S C R-1)+\overline{\beta X}, & \text { if } D S C R<1.0 \\ \alpha_{i}+\beta_{D S C R} D S C R+\overline{\beta X}, & \text { otherwise }\end{array}\right.$

This formulation creates a continuous probability distribution with a kink at the spline knot threshold. Ideally, we would like to add additional knots at various intervals below 1.0; however, due to the small number of observed delinquencies in the sample (even at the more extreme values of LTV and DSCR) we were unable to do so without running into significant identification issues. Nevertheless, even with only one knot, the results indicate that a rethinking of the specifications used to predict default and prepayment in commercial loans may be in order. In Table 5, we observe that at levels of DSCR below 1.0, the probability of delinquency increases substantially with a decline in DSCR. In Figure 7 we plot out the default probability at mean values for other variables and at the lowest levels of DSCR, the probability of delinquency rises to almost $9 \%$ - much more than without the spline. At the higher levels of DSCR, delinquency is low, but notably non-zero. The suggestion here is that at higher levels of DSCR, delinquency is governed by more idiosyncratic, property-specific forces, while at lower levels market forces play a stronger role. This notion has been advanced recently by Gibson (2001). For the 
prepayment outcome, the spline specification performs poorly. At lower levels of DSCR, the probability of prepayment increases, which would run counter to our intuition. The model performs poorly for both outcomes where LTV is the chosen measure of loan stress.

In Figures $8 \mathrm{a}$ and 8b, we graph the conditional and cumulative baseline hazard of delinquency using the set of spell period fixed effects that we estimated in our spline specification. We illustrate a family of baseline hazards - at different contemporaneous DSCR values. Consistent with previous literature, the unconditional baseline hazard is indeed hump-shaped, with a probability of delinquency of nearly zero in the last three years of the sample. ${ }^{4}$ This pattern suggests that it takes a couple of years for problems to swell to a point that an owner will have trouble servicing his property's debt. Once the most vulnerable years have passed, surviving loans are likely to continue performing without incident.

\section{Discussion and Conclusions}

The default and delinquency rates of loans in the CMBS pool have been unusually low over the last decade and with few exceptions has remained low even during the economic turbulence of the last three years. All together since 1992, some of the markets in which CMBS collateral resides have seen periods of significant stress. In our sample, loans do end up with an estimated DSCR of below 1.0 due to market declines: Austin apartments (a 35\% NOI decline between 1999 and 2002), Atlanta retail (a 25\% NOI decline between 1992 and 1996) and New York office properties (a 30\% NOI decline between 1992 and 1996), to name just a few. In our analysis, periods of decline like these tend to lower DSCR enough to raise the annual default rate from a "baseline" value of 0.5-1.0\% into the 5.0-9.0\% range. While highly significant statistically, these elevations are much less than occurred in the early 1990s.

So, how do we explain the low estimated probabilities of delinquency in our analysis? Two possibilities come to mind. First, the NOI and Value indices used to update the reported measures of loan stress were may contain significant "noise" - as measures of actual property NOI and LTV - since they are based only on the "market"

\footnotetext{
${ }^{4}$ The general shape holds under all of our other specifications as well.
} 
forces driving the changes in a loan's collateral. Furthermore, the market level considered is the property's MSA - not a particular submarket or location. Each loan's collateral is subjected to these market wide shocks only to the extent a "rising tide raises all boats". In addition, collateral will be subject to property-specific shocks that are not necessarily related to market changes: a major tenant's leave, a building's need of significant repairs, etc. If such idiosyncratic shocks are more important than market-based changes in determining default, then the use of a purely market-based adjustment index will introduce a significant amount of measurement error. It may be the case that our model is simply straying too far "out of sample," and that loans with true DSCR significantly below 1.0 do default almost every time - it is simply the case that the properties in our sample have not experienced the occasionally severe market-level shocks exhibited by our constructed indices.

The second explanation for our result is that some of the theoretical ideas advanced in favor of "gentle" default are in fact true. Data from the early 1990's suggest that property values declined dramatically along with income streams. In the case of a "hundred year flood", lenders have little option but to foreclose. Borrowers, as well, find that traditional methods of avoiding foreclosure, such as cross-collateralized income, do not work, since all collateral is experiencing stress. Kiyotaki and Moore (1997) have developed such arguments into a full fledged theory of credit cycles. In the CMBS pool, however, the situation over the last decade has been a bit different: stress has been more market and property type specific. Furthermore, in recent years, low interest rates have kept property values high (and LTV low) even though property incomes (and DSCR) may have declined. With stress potentially confined to more isolated areas of borrowers' portfolios, lenders (wishing to avoid the considerable costs of termination) may have extended considerable leeway, thus enabling borrowers to avoid default. Our empirical results tend to support this argument to the extent that LTV is less effective at predicting default than is DSCR.

All in all, we believe that the addition of contemporaneous loan stress, even with the shortcomings of the measures used here, represents a significant improvement over previous research. More importantly it provides an important benchmark for future 
research. If we are to gain a better understanding of lender-borrower behavior around termination events, contemporaneous measures of loan stress are essential.

The authors are indebted to Trepp, LLC and Torto Wheaton Research for the provision of data. We would also like to thank David Geltner, Tony Ciochetti, Ray Torto, Tom Thibodeau, Timothy Riddiough, Yongheng Deng, Steve Phillips and Paul Manchester for their helpful comments. The Authors remain fully responsible for all conclusions and analysis drawn from this research. 


\section{References}

Ambrose, B.W. and A.B. Sanders. 2003. Commercial Mortgage-Backed Securities: Prepayment and Default. Journal of Real Estate Finance and Economics 2/3:179-196

Borsch-Supan, A. 1990. Panel Data Analysis of Housing Choices. Regional Science and Urban Economics 1:65-82.

Ciochetti, B. and K.A. Vandell. 1999. The Performance of Commercial Mortgages. Real Estate Economics 1:27-62.

Ciochetti, B., Y. Deng, B. Gao and R. Yao. 2002. The Termination of Lending Relationships through Prepayment and Default in Commercial Mortgage Markets: A Proportional Hazard Approach with Competing Risks. Real Estate Economics 4:595633.

Deng, Y., J. Quigley and R. Van Order. 2000. Mortgage Terminations, Heterogeneity, and the Exercise of Mortgage Options. Econometrica 2:275-307.

Esaki, H., S. L’Huereux, and M. Snyderman. 1999. Commercial Mortgage Defaults: An Update. Real Estate Finance 1:80-86.

Follain, J.R., and J. Ondrich. 1997. Ruthless Prepayment? Evidence from Multi-Family Mortgages. Journal of Urban Economics 1:78-101.

Gibson, M. 2001. Incorporating Event Risk into Value-at-Risk. Board of Governors of the Federal Reserve System Working Paper.

Han, A. and J.A. Hausman. 1990. Flexible Parametric Estimation of Duration and Competing Risk Models. Journal of Applied Econometrics 1:1-28.

Kau, J.B., D.C. Keenan, W.J. Muller, and J.F. Epperson. 1990. Pricing Commercial Mortgages and their Mortgage Backed Securities. Journal of Real Estate Finance and Economics 4:333-356.

Kau, J.B., D.C. Keenan, and T. Kim. 1994. Default Probabilities for Mortgages. Journal of Urban Economics 3:278-296.

Kiyotaki, N. and J. Moore. 1997. Credit Cycles. Journal of Political Economy. 2:211248.

Lekkas, V., J.M. Quigley and R. Van Order. 1993. Loan Loss Severity and Optimal Mortgage Default. Real Estate Economics, 4:353-372.

McConnell, J.J. and M. Singh. 1994. Rational Prepayments and the Valuation of Collateralized Mortgage Obligations. Journal of Finance 3:891-921. 
Riddiough, T. J. and H.R. Thompson. 1993. Commercial Mortgage Default Pricing with Unobservable Borrower Default Costs. Real Estate Economics 3:256-291.

Riddiough, T. J. and S.B. Watt. 1994. Strategic Default, Workout, and Commercial Mortgage Valuation. Real Estate Economics 3:5-22.

Vandell, K. 1992. Predicting Commercial Mortgage Foreclosure Experience. Real Estate Economics 1:55-88.

Snyderman, M.P. 1991. Commercial Mortgages: Default Occurrence and Estimated Yield Impact. Journal of Portfolio Management 1:82-87.

Vandell, K., W. Barnes, D. Hartzell, D. Kraft, and W. Wendt. 1993. Commercial Mortgage Defaults: Proportional Hazards Estimation Using Individual Loan Histories. Journal of the American Real Estate and Urban Economics Association 4:451-480. 
Table 1a: Results, initial LTV alone, bracketed measures of initial LTV

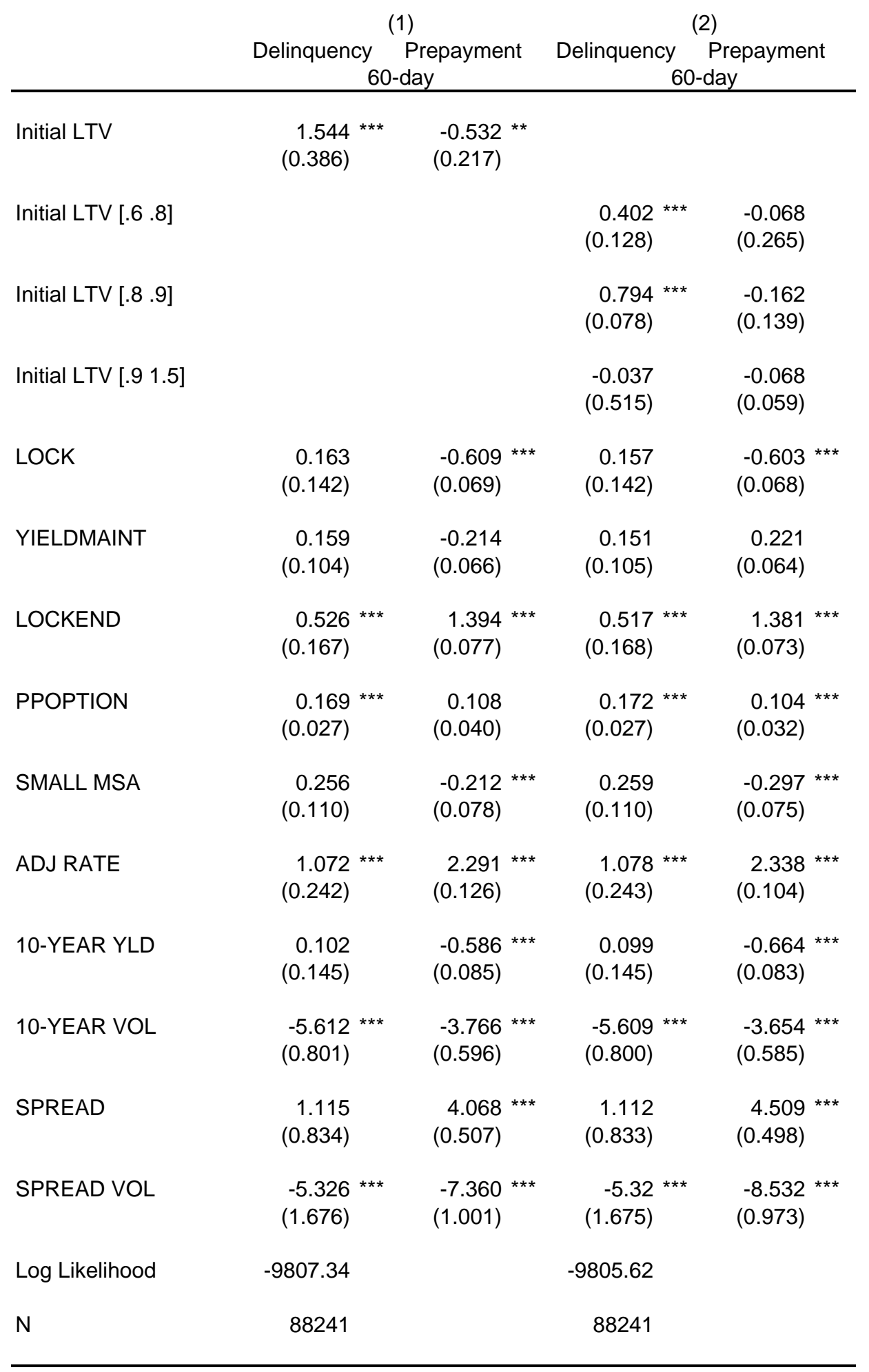

Initial LTV (continuous measure) bounded between 0.1 and 1.5.

All models estimated with spell and origination period fixed effects

Robust standard errors in parentheses.

${ }^{*},{ }^{* *}$, and ${ }^{* * *}$ represent significance at the $10 \%, 5 \%$, and $1 \%$ levels, respectively 
Table 1b: Results, initial DSCR alone, bracketed measures of initial DSCR

(1) (2)

Delinquency Prepayment Delinquency Prepayment 60-day

60-day

\begin{tabular}{|c|c|c|c|c|}
\hline Initial DSCR & $\begin{array}{l}-1.580 \text { *** } \\
(0.183)\end{array}$ & $\begin{array}{l}0.140 \text { ** } \\
(0.055)\end{array}$ & & \\
\hline Initial DSCR [.5 .8] & & & $\begin{array}{l}1.846 \text { *** } \\
(0.169)\end{array}$ & $\begin{array}{l}-0.483 \text { *** } \\
(0.160)\end{array}$ \\
\hline Initial DSCR [.8 1.0] & & & $\begin{array}{l}1.068 \text { *** } \\
(0.155)\end{array}$ & $\begin{array}{l}-0.522 \\
(0.114)\end{array}$ \\
\hline Initial DSCR [1.0 1.3] & & & $\begin{array}{l}0.666 \text { *** } \\
(0.119)\end{array}$ & $\begin{array}{r}-0.024 \\
(0.066)\end{array}$ \\
\hline LOCK & $\begin{array}{r}0.162 \\
(0.159)\end{array}$ & $\begin{array}{l}-0.568 \text { *** } \\
(0.075)\end{array}$ & $\begin{array}{r}0.154 \\
(0.159)\end{array}$ & $\begin{array}{l}-0.578 \text { *** } \\
(0.076)\end{array}$ \\
\hline YIELDMAINT & $\begin{array}{r}0.130 \\
(0.119)\end{array}$ & $\begin{array}{r}0.155 \\
(0.072)\end{array}$ & $\begin{array}{r}0.125 \\
(0.119)\end{array}$ & $\begin{array}{r}0.149 \\
(0.072)\end{array}$ \\
\hline LOCKEND & $\begin{array}{l}0.694 \text { *** } \\
(0.179)\end{array}$ & $\begin{array}{l}1.343^{* * *} \\
(0.088)\end{array}$ & $\begin{array}{l}0.707^{\text {*** }} \\
(0.179)\end{array}$ & $\begin{array}{l}1.331 \text { *** } \\
(0.088)\end{array}$ \\
\hline PPOPTION & $\begin{array}{l}0.206 \text { *** } \\
(0.038)\end{array}$ & $\begin{array}{l}0.133 \text { ** } \\
(0.048)\end{array}$ & $\begin{array}{l}0.204^{* * *} \\
(0.040)\end{array}$ & $\begin{array}{l}0.136 \text { ** } \\
(0.049)\end{array}$ \\
\hline SMALL MSA & $\begin{array}{r}0.245 \\
(0.122)\end{array}$ & $\begin{array}{l}-0.342 \\
(0.082)\end{array}$ & $\begin{array}{r}0.257 \\
(0.122)\end{array}$ & $\begin{array}{l}-0.353 \text { *** } \\
(0.083)\end{array}$ \\
\hline 10-YEAR YLD & $\begin{array}{r}0.284 \\
(0.165)\end{array}$ & $\begin{array}{l}-1.054 \text { *** } \\
(0.106)\end{array}$ & $\begin{array}{r}0.287 \\
(0.164)\end{array}$ & $\begin{array}{l}-1.066 \text { *** } \\
(0.107)\end{array}$ \\
\hline 10-YEAR VOL & $\begin{array}{l}-4.834 \text { *** } \\
(0.914)\end{array}$ & $\begin{array}{l}-5.772 \text { *** } \\
(0.805)\end{array}$ & $\begin{array}{l}-4.904^{* * *} \\
(0.915)\end{array}$ & $\begin{array}{l}-5.813^{* * *} \\
(0.810)\end{array}$ \\
\hline SPREAD & $\begin{array}{r}0.028 \\
(0.949)\end{array}$ & $\begin{array}{l}5.668 \text { *** } \\
(1.161)\end{array}$ & $\begin{array}{r}0.055 \\
(0.946)\end{array}$ & $\begin{array}{l}5.707^{* * *} \\
(0.635)\end{array}$ \\
\hline SPREAD VOL & $\begin{array}{l}-3.360 \text { ** } \\
(1.801)\end{array}$ & $\begin{array}{l}-10.75^{* * *} \\
(1.161)\end{array}$ & $\begin{array}{l}-3.420 \text { ** } \\
(1.805)\end{array}$ & $\begin{array}{l}-10.85 \text { *** } \\
(1.164)\end{array}$ \\
\hline Log Likelihood & -7546.82 & & -7536.13 & \\
\hline $\mathrm{N}$ & 77624 & & 77624 & \\
\hline
\end{tabular}

Initial DSCR (continuous measure) bounded between 0.5 and 5 .

All models estimated with spell and origination period fixed effects

Robust standard errors in parentheses.

${ }^{*}, * \star$, and ${ }^{\star \star \star}$ represent significance at the $10 \%, 5 \%$, and $1 \%$ levels, respectively 
Table 2: Results, competing risks model with contemporaneous measures of loan stress

\begin{tabular}{|c|c|c|c|c|c|c|}
\hline \multirow{3}{*}{ DSCR } & \multicolumn{2}{|c|}{$(1)$} & \multicolumn{2}{|c|}{$(2)$} & \multicolumn{2}{|c|}{$(3)$} \\
\hline & \multirow{2}{*}{$\begin{array}{c}\text { Delinquency } \\
60 \\
-1.693 \text { *** } \\
(0.187)\end{array}$} & \multirow{2}{*}{$\begin{array}{l}\text { repayment } \\
\begin{array}{l}\text { ay } \\
0.180 * * * \\
(0.040)\end{array}\end{array}$} & \multirow[t]{2}{*}{$\begin{array}{r}\text { Delinquency } \\
60 \\
\end{array}$} & \multirow[t]{2}{*}{$\begin{array}{l}\text { Prepayment } \\
\text { day }\end{array}$} & \multirow{2}{*}{\multicolumn{2}{|c|}{$\begin{array}{cc}\text { Delinquency } & \text { Prepayment } \\
\text { 60-day } & \\
& \\
-1.668 * \star * & 0.117^{* \star \star} \\
(0.193) & (0.046)\end{array}$}} \\
\hline & & & & & & \\
\hline LTV & & & $\begin{array}{l}1.693 \text { *** } \\
(0.275)\end{array}$ & $\begin{array}{l}-0.874 \text { *** } \\
(0.185)\end{array}$ & $\begin{array}{r}0.285 \\
(0.358)\end{array}$ & $\begin{array}{r}-0.733 \\
(0.219)\end{array}$ \\
\hline LOCK & $\begin{array}{r}0.156 \\
(0.163)\end{array}$ & $\begin{array}{l}-0.5944^{* * *} \\
(0.077)\end{array}$ & $\begin{array}{r}0.150 \\
(0.141)\end{array}$ & $\begin{array}{l}-0.609 \text { *** } \\
(0.069)\end{array}$ & $\begin{array}{r}0.151 \\
(0.163)\end{array}$ & $\begin{array}{l}-0.590 * * * \\
(0.072)\end{array}$ \\
\hline YIELDMAINT & $\begin{array}{r}-0.112 \\
(0.125)\end{array}$ & $\begin{array}{r}0.150 \\
(0.074)\end{array}$ & $\begin{array}{r}0.154 \\
(0.108)\end{array}$ & $\begin{array}{r}-0.214 \\
(0.066)\end{array}$ & $\begin{array}{r}0.116 \\
(0.124)\end{array}$ & $\begin{array}{l}0.147 \text { ** } \\
(0.077)\end{array}$ \\
\hline LOCKEND & $\begin{array}{l}0.770 \text { *** } \\
(0.187)\end{array}$ & $\begin{array}{l}1.345 \text { *** } \\
(0.091)\end{array}$ & $\begin{array}{l}0.5944^{\star * \star} \\
(0.174)\end{array}$ & $\begin{array}{l}1.394^{\star * * \star} \\
(0.077)\end{array}$ & $\begin{array}{l}0.762 \text { *** } \\
(0.188)\end{array}$ & $\begin{array}{l}1.346 \text { *** } \\
(0.091)\end{array}$ \\
\hline PPOPTION & $\begin{array}{l}0.1988^{\star \star \star} \\
(0.044)\end{array}$ & $\begin{array}{l}0.138 \text { ** } \\
(0.050)\end{array}$ & $\begin{array}{l}0.162 \text { *** } \\
(0.034)\end{array}$ & $\begin{array}{r}0.108 \\
(0.040)\end{array}$ & $\begin{array}{l}0.201 \text { *** } \\
(0.055)\end{array}$ & $\begin{array}{r}0.134 \\
(0.069)\end{array}$ \\
\hline SMALL MSA & $\begin{array}{r}0.064 \\
(0.127)\end{array}$ & $\begin{array}{l}-0.275^{\text {*** }} \\
(0.085)\end{array}$ & $\begin{array}{r}0.172 \\
(0.116)\end{array}$ & $\begin{array}{l}-0.2122^{* \star *} \\
(0.078)\end{array}$ & $\begin{array}{r}0.047 \\
(0.129)\end{array}$ & $\begin{array}{l}-0.226 \text { *** } \\
(0.085)\end{array}$ \\
\hline ADJ RATE & & & $\begin{array}{l}0.969 \text { *** } \\
(0.252)\end{array}$ & $\begin{array}{l}2.291 \text { *** } \\
(0.126)\end{array}$ & & \\
\hline 10-YEAR YLD & $\begin{array}{r}0.210 \\
(0.165)\end{array}$ & $\begin{array}{l}-0.293^{\text {*** }} \\
(0.085)\end{array}$ & $\begin{array}{r}-0.070 \\
(0.148)\end{array}$ & $\begin{array}{l}-0.586 \text { *** } \\
(0.085)\end{array}$ & $\begin{array}{r}0.203 \\
(0.165)\end{array}$ & $\begin{array}{l}-0.961 \text { *** } \\
(0.111)\end{array}$ \\
\hline 10-YEAR VOL & $\begin{array}{l}-4.552 \text { *** } \\
(0.881)\end{array}$ & $\begin{array}{l}-5.847 * * * \\
(0.822)\end{array}$ & $\begin{array}{l}-5.381 \text { *** } \\
(0.784)\end{array}$ & $\begin{array}{l}-3.766 \text { *** } \\
(0.596)\end{array}$ & $\begin{array}{l}-4.547 \text { *** } \\
(0.882)\end{array}$ & $\begin{array}{l}-5.918 \text { *** } \\
(0.826)\end{array}$ \\
\hline SPREAD & $\begin{array}{r}0.104 \\
(0.970)\end{array}$ & $\begin{array}{l}5.152 * * * \\
(0.650)\end{array}$ & $\begin{array}{r}1.110 \\
(0.860)\end{array}$ & $\begin{array}{l}4.068 \text { *** } \\
(0.507)\end{array}$ & $\begin{array}{r}0.114 \\
(0.972)\end{array}$ & $\begin{array}{l}5.157^{\star * *} \\
(0.654)\end{array}$ \\
\hline SPREAD VOL & $\begin{array}{l}-3.826 \text { ** } \\
(1.903)\end{array}$ & $\begin{array}{l}-9.2677^{* * *} \\
(1.211)\end{array}$ & $\begin{array}{l}-5.324 \text { *** } \\
(1.775)\end{array}$ & $\begin{array}{l}-7.360 \text { *** } \\
(1.001)\end{array}$ & $\begin{array}{l}-3.861 \text { ** } \\
(1.908)\end{array}$ & $\begin{array}{l}-9.3244^{\star \star \star} \\
(1.211)\end{array}$ \\
\hline Log Likelihood & -7061.94 & & -9428.06 & & -7052.92 & \\
\hline N & 77624 & & 84326 & & 77553 & \\
\hline
\end{tabular}

Initial LTV bounded between 0.1 and 1.5; Initial DSCR bounded between 0.5 and 5 .

All models estimated with spell and origination period fixed effects

Robust standard errors in parentheses.

${ }^{*}, * *$, and ${ }^{* \star *}$ represent significance at the $10 \%, 5 \%$, and $1 \%$ levels , respectively 
Table 3a: Bracketed measures of contemporaneous LTV

\begin{tabular}{|c|c|c|}
\hline & \multicolumn{2}{|c|}{ 60-day } \\
\hline LTV [.6 .8] & $\begin{array}{l}0.828 \text { *** } \\
(0.627)\end{array}$ & $\begin{array}{r}-0.124 \\
(0.088)\end{array}$ \\
\hline LTV [.8 .9] & $\begin{array}{l}-0.242 \text { *** } \\
(0.053)\end{array}$ & $\begin{array}{l}-0.262 \\
(0.043)\end{array}$ \\
\hline LTV [.9 1.5] & $\begin{array}{l}-0.083 \text { ** } \\
(0.039)\end{array}$ & $\begin{array}{r}0.018 \\
(0.026)\end{array}$ \\
\hline Log Likelihood & -8920.72 & \\
\hline $\mathrm{N}$ & 84326 & \\
\hline
\end{tabular}

Table 3b: Bracketed measures of contemporaneous DSCR

\begin{tabular}{|c|c|c|}
\hline & \multicolumn{2}{|c|}{ 60-day } \\
\hline DSCR [0 .8] & $\begin{array}{l}0.838 \text { *** } \\
(0.079)\end{array}$ & $\begin{array}{r}-0.136 \\
(0.133)\end{array}$ \\
\hline DSCR [.8 1.0] & $\begin{array}{l}0.265^{\text {*** }} \\
(0.055)\end{array}$ & $\begin{array}{l}-0.253 \\
(0.046)\end{array}$ \\
\hline DSCR [1.0 1.3] & $\begin{array}{l}0.134 \text { *** } \\
(0.042)\end{array}$ & $\begin{array}{r}-0.009 \\
(0.029)\end{array}$ \\
\hline Log Likelihood & -6914.3 & \\
\hline $\mathrm{N}$ & 77624 & \\
\hline
\end{tabular}

Initial LTV (continuous measure) bounded between 0.1 and 1.5. Initial DSCR bounded between 0.5 and 5 .

All models estimated with spell period fixed effects

Robust standard errors in parentheses.

${ }^{*},{ }^{* *}$, and ${ }^{* * *}$ represent significance at the $10 \%, 5 \%$, and $1 \%$ levels, respectively Additional regressors identical to those in Table $1 \mathrm{a}$ and $\mathrm{b}$. 


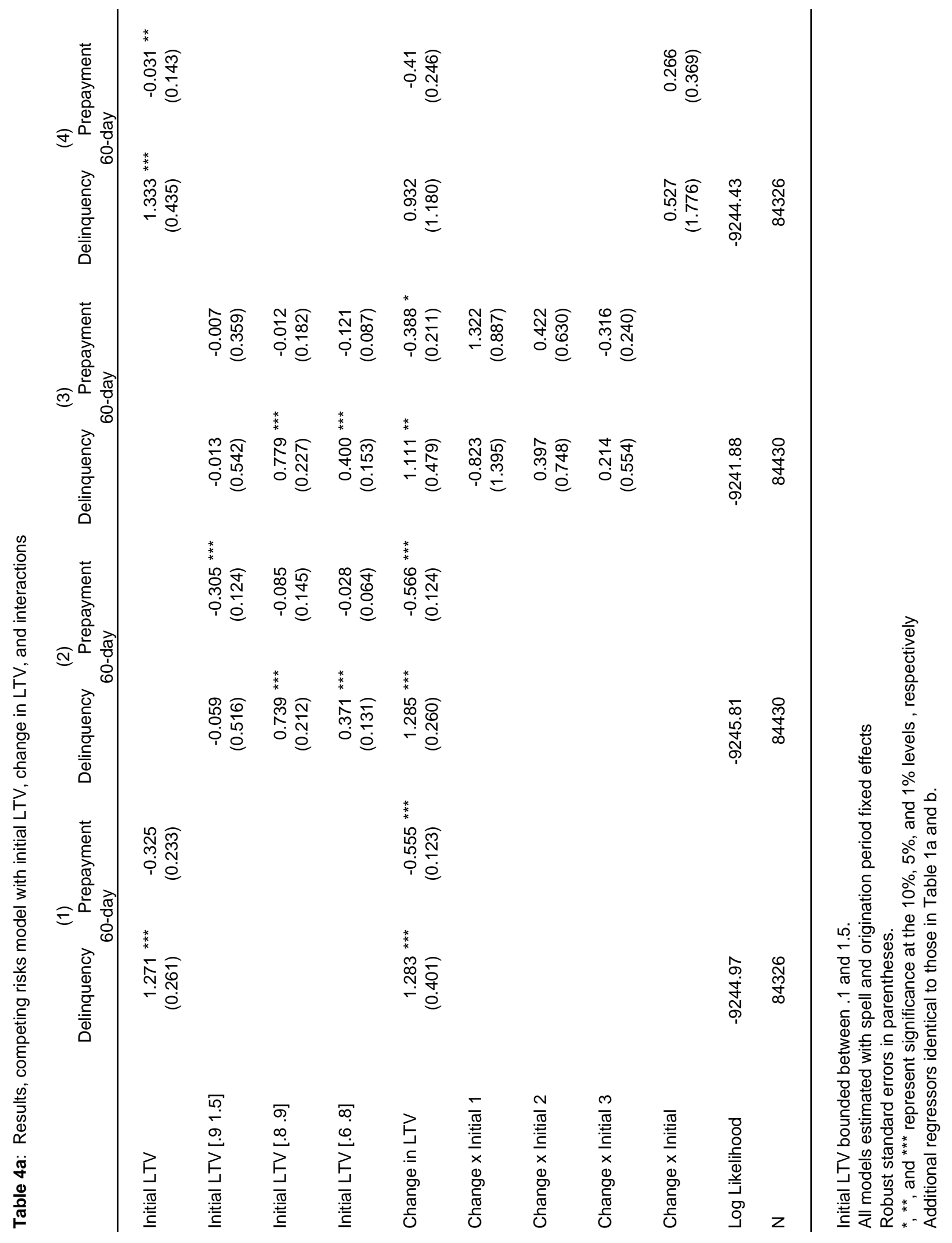




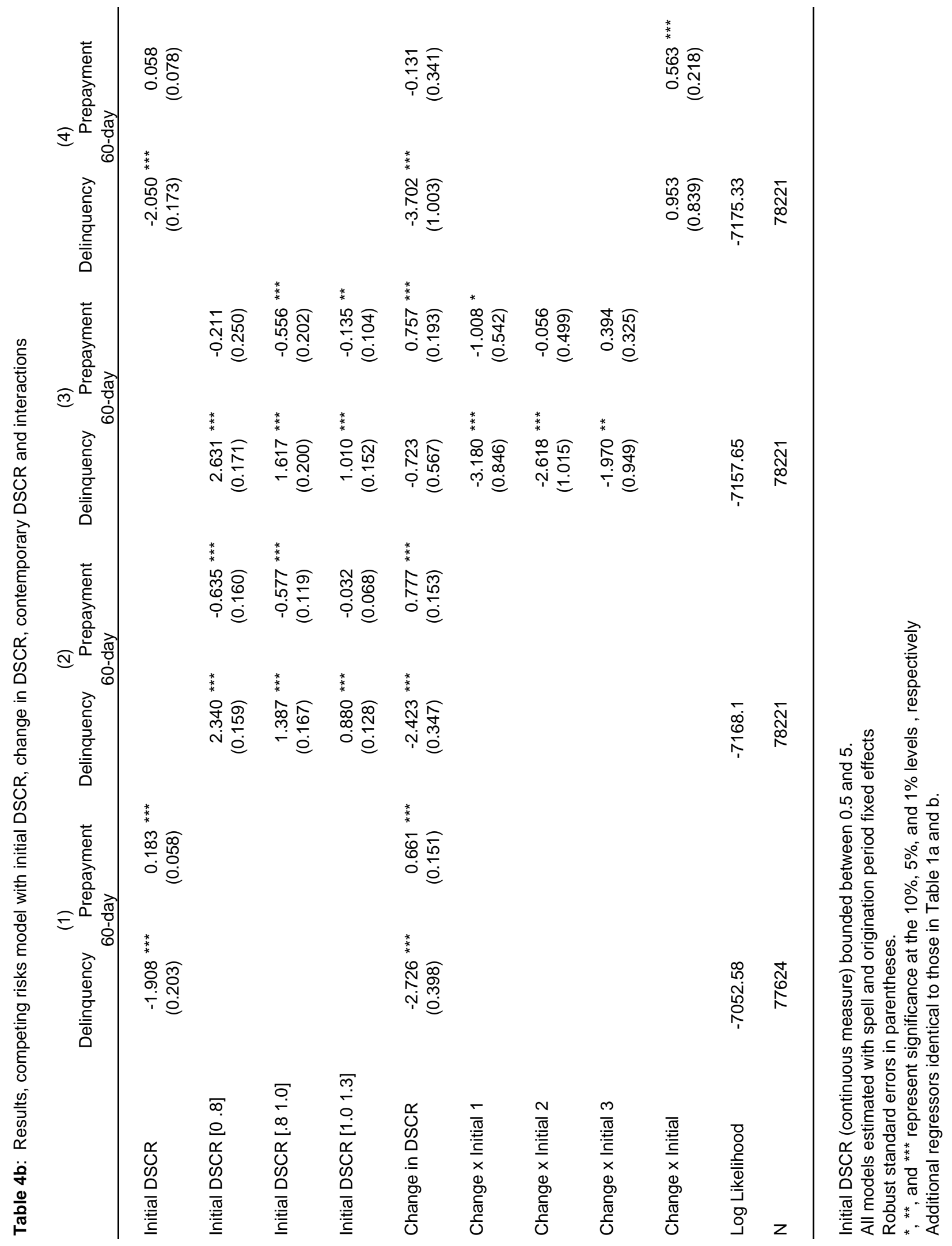


Table 5

Spec. test, competing risks model with spline for contemporary DSCR $<1$

\begin{tabular}{|c|c|c|}
\hline & \multicolumn{2}{|c|}{ 60-day } \\
\hline DSCR & $\begin{array}{l}-1.412 \text { *** } \\
(0.180)\end{array}$ & $\begin{array}{l}0.176 \\
(0.042)\end{array}$ \\
\hline Spline knot $^{a}$ & $\begin{array}{l}-1.857 \text { *** } \\
(0.454)\end{array}$ & $\begin{array}{l}-0.427 \text { * } \\
(0.224)\end{array}$ \\
\hline Log Likelihood & -7124.8 & \\
\hline $\mathrm{N}$ & 77995 & \\
\hline
\end{tabular}

Initial DSCR bounded between 0.3 and 5

Model estimated with spell period fixed effects

Robust standard errors in parentheses.

${ }^{*},{ }^{*}$, and ${ }^{* \star *}$ represent significance at the $10 \%, 5 \%$, and $1 \%$ levels, respectively Additional regressors identical to those in Table $1 \mathrm{a}$ and $\mathrm{b}$.

${ }^{a}$ defined by DSCR*I(DSCR $\left.<1\right)-I(D S C R<1)$ 

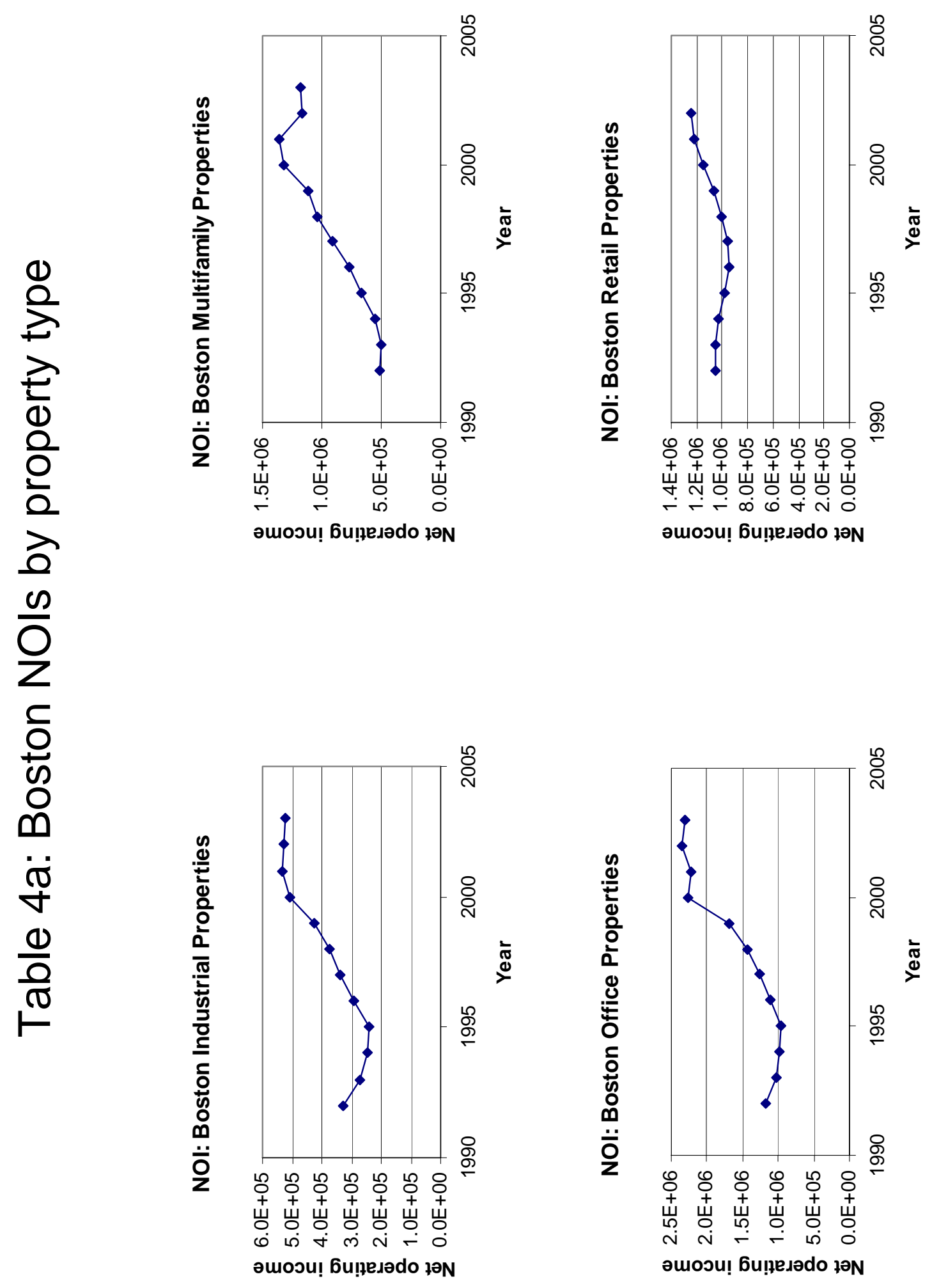

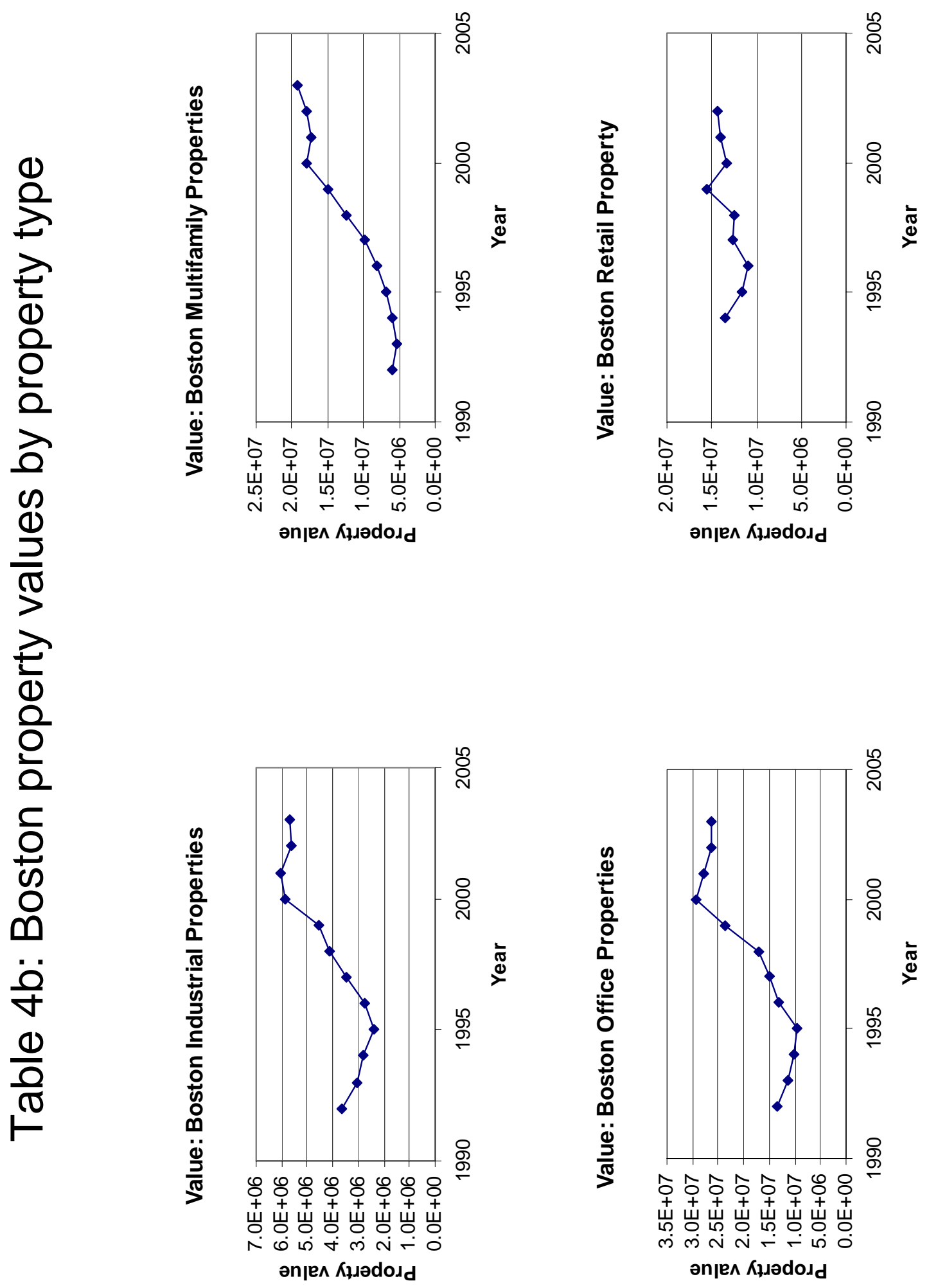

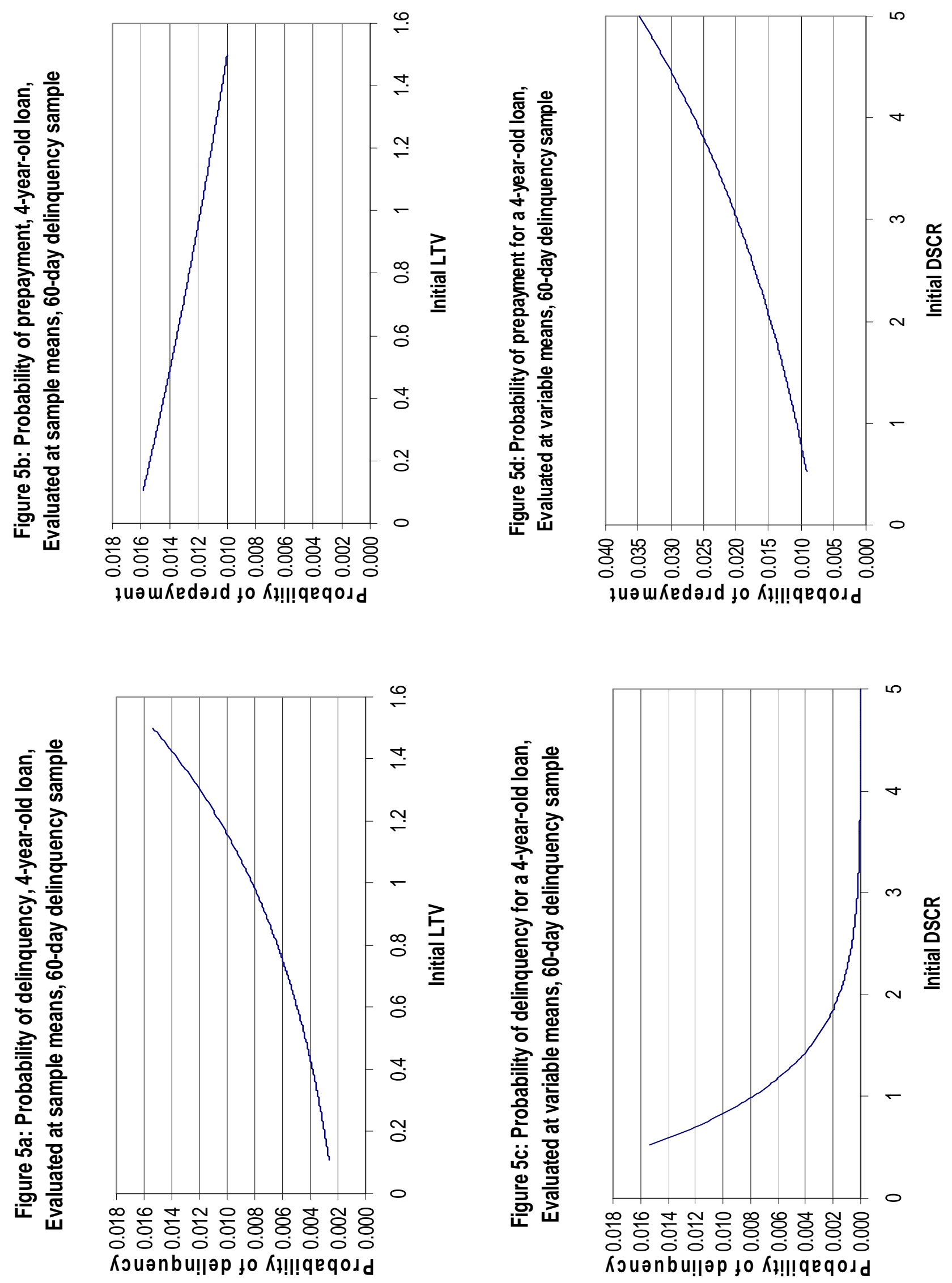

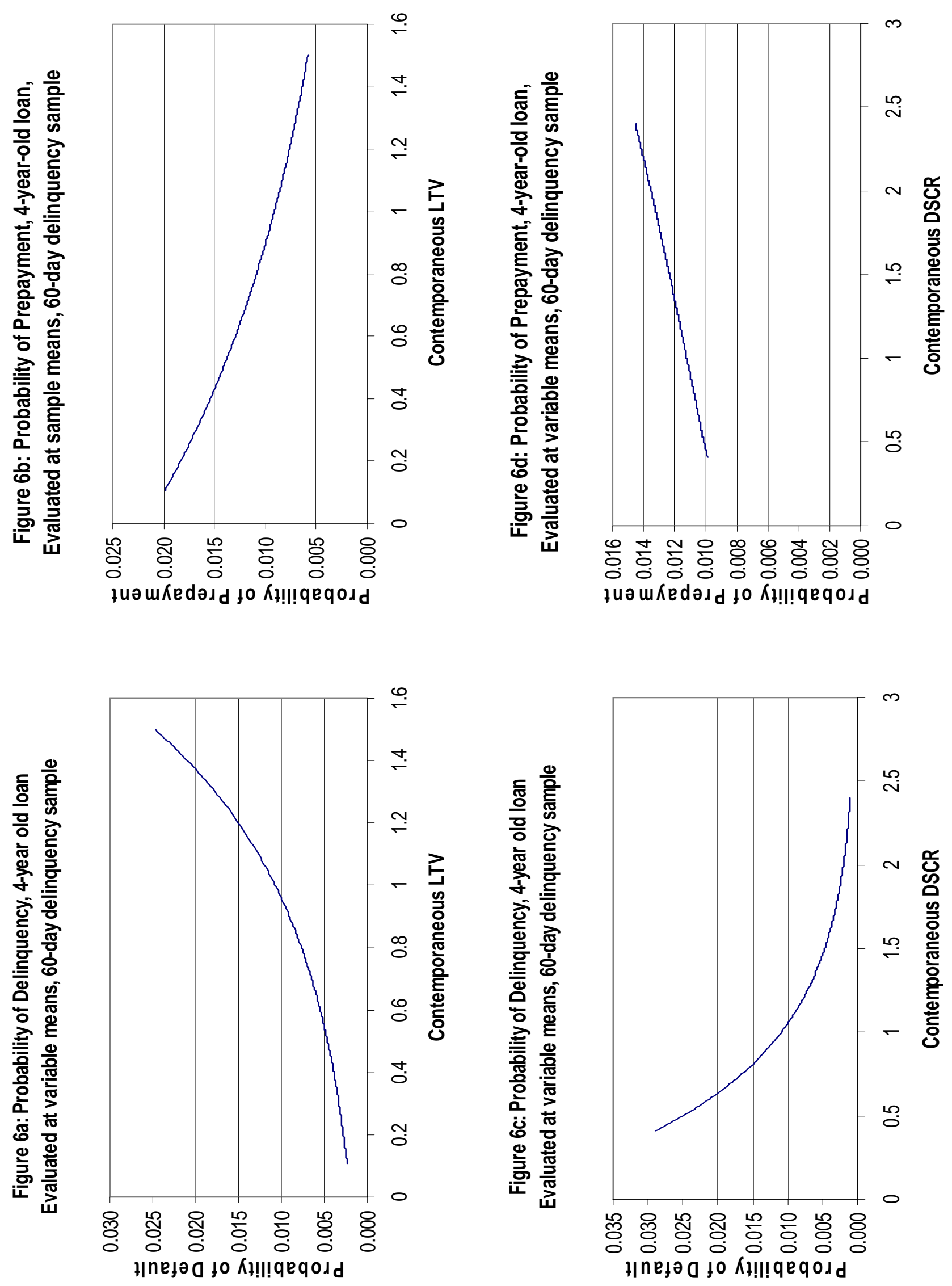


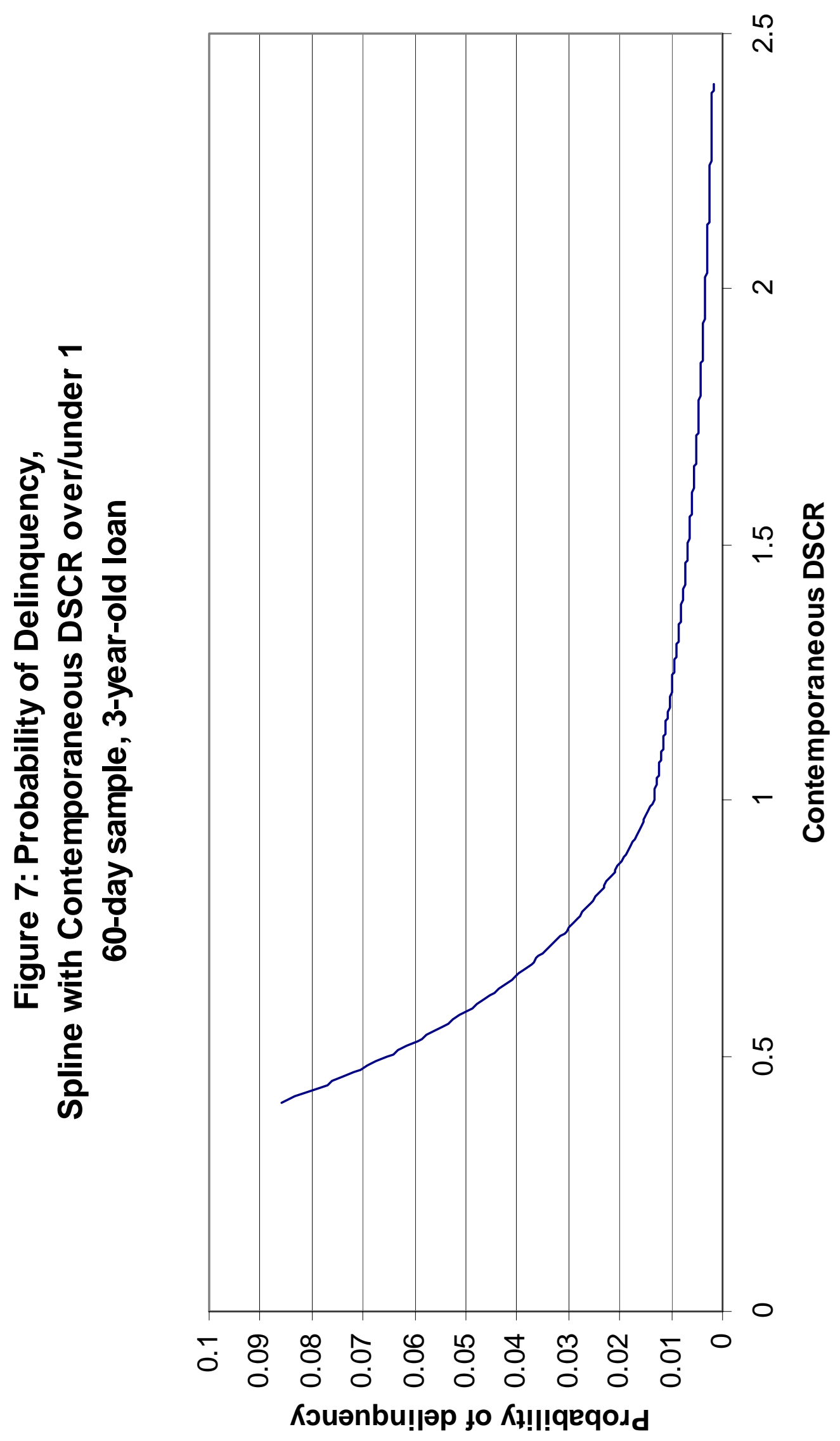


Figure 8a: Yearly probability of default

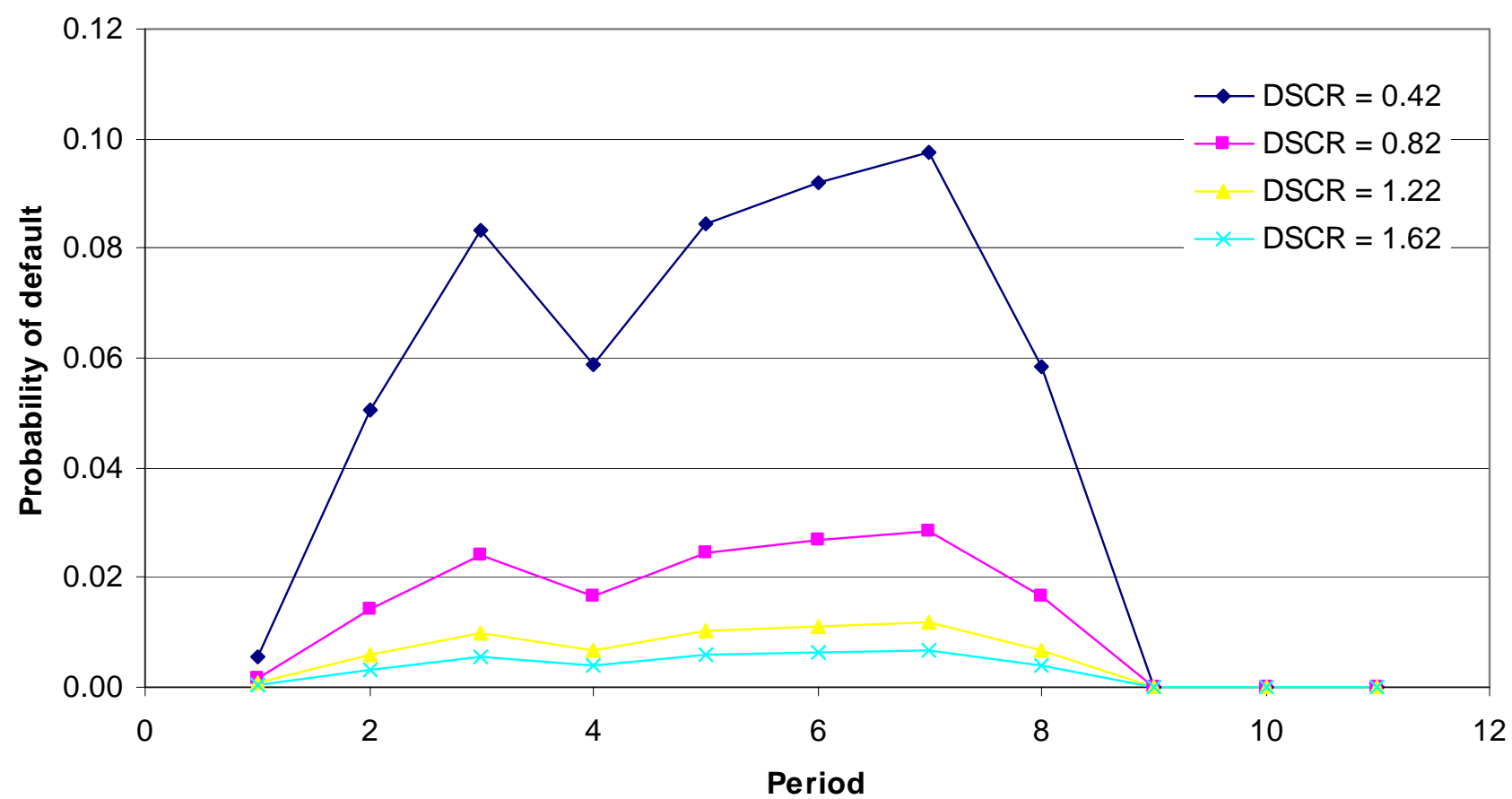

Figure 8b: Cumulative probability of default

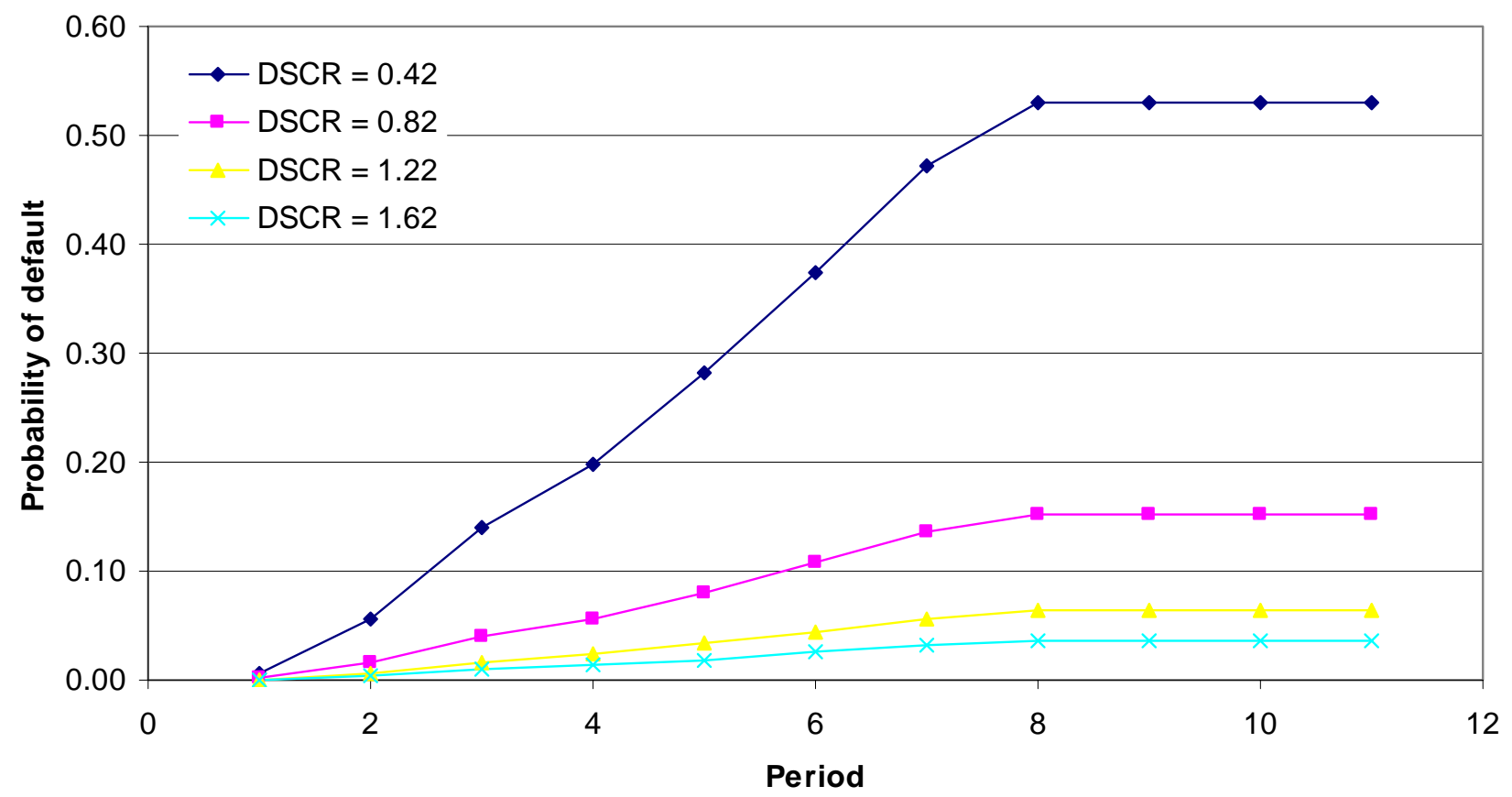

